\title{
EVALUATION OF RAW MATERIALS AND THEIR SUPPLIERS AS A DEFENCE AGAINST FOOD FRAUD
}

\author{
Justyna GÓRNA \\ Uniwersytet Ekonomiczny w Poznaniu; justyna.gorna@ue.poznan.pl, ORCID: 0000-0002-2763-5810
}

Purpose: The main purpose of this article was to present the actions taken by the food manufacturer in the field of its defence against fraud.

Design/methodology/approach: Ensuring food safety requires the active participation of the enterprise on two levels, preventing accidental and intentional food contamination. In order to supervise the area related to accidental food contamination, obligatory HACCP system and voluntary quality and safety management standards are implemented in enterprises. These include ISO 22000, FSSC 22000, BRC or IFS. In turn, the area related to intentional food contamination requires action to reduce the risk of food contamination and food fraud. The adopted methodology for the evaluation of raw materials and their suppliers in the food fraud area is based on the IFS guidelines, as well as an approach developed by the author of this study, who participated in the implementation of this methodology in the company.

Findings: The analyzed company is characterized by having a high cultural level of food safety and quality - actions are taken there to support its development at various levels. Among these are leadership, communication, employee involvement and risk awareness. This approach guarantees that the developed product fraud reduction plan will positively evolve in this company so as to meet and surmount changing risk factors.

Originality/value: The article presents the practical application of IFS guidelines in the area of food fraud. In addition, a template for the vulnerability assessment form was designed and criteria for the assessment of control measures were specified.

Keywords: food fraud, suppliers evaluation, assessment of raw materials

Category of the paper: Case study.

\section{Introduction}

Ensuring food safety depends on many factors. These include food law, human behavior, management systems and organizational culture, and activities related to the prevention/ minimization/elimination of microbiological, chemical and physical hazards (Manning, Baines, 2004). Legal requirements set out rules for monitoring the use of raw materials and rules for handling them. This is primarily aimed at preventing, eliminating or minimizing the occurrence 
of microbiological, chemical and physical hazards. The extent to which the company meets legal requirements and ensures proper handling of raw materials, finished products or the production process will probably depend on the management system adopted in the organization and its culture (Górna, 2018, p. 102).

Ensuring food safety boils down to supervising threats introduced unintentionally and those threats that may appear as a result of planned (intentional) actions. Threats introduced unintentionally are supervised as part of the obligatory HACCP (Hazard Analysis and Critical Control Point) system. Intentional threats include threats related to an ideologically motivated food attack - this area is supported by the TACCP (Threat Assessment Critical Control Point) tool. However, when the motivation of an attack on food is the desire to obtain economic benefits, and the effect of these actions is fraud (e.g. food /raw material counterfeiting), then to ensure food safety, the VACCP (Vulnerability Assessment and Critical Control Points) tool can be used (Górna, 2019) (Figure 1). Product fraud is the intentional and deliberate substitution (substitution), falsification or counterfeiting of food, raw materials, additives or packaging, and improper labeling.

\section{ASSURANCE FOOD SAFETY}

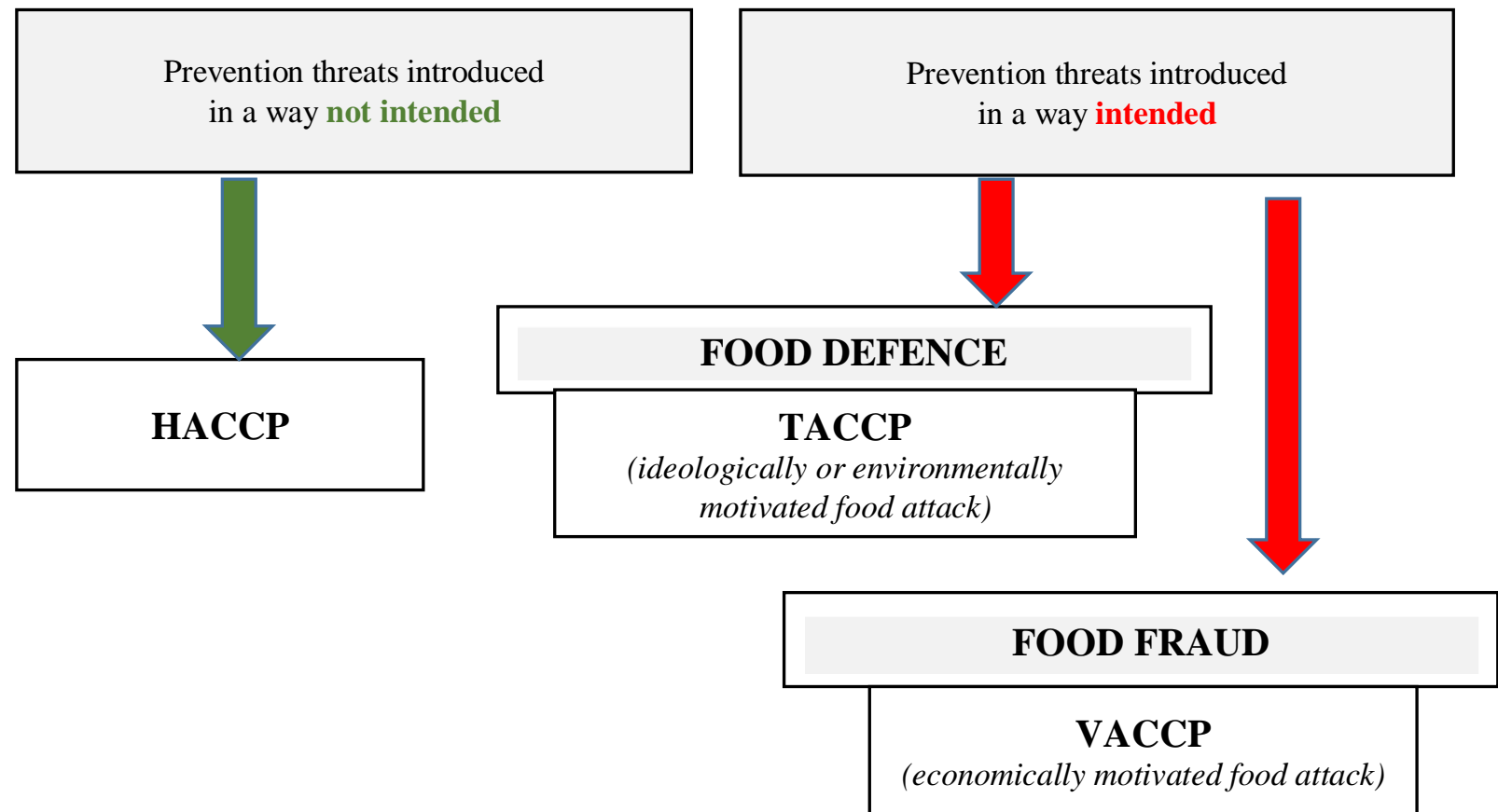

Figure 1. Tools used to ensure of food safety.

The practice of adulterating foods is as old as the art of buying and selling food for cash or commodities. In ancient Rome and Athens, laws were enacted regarding the adulteration of wines with flavors and colors. However, it was not until the thirteenth century that Europe saw the beginnings of legislation prohibiting food adulteration when France and Germany passed 
food control statutes and King John in England issued a proclamation regarding penalties for the adulteration of bread. More extensive legislation regarding adulteration of human food was passed by Henry III (Sumar, and Imail, 1995). Food counterfeiting and fraud have long ago forced specific actions to limit this practice. The first Food Adulteration Act was passed in 1860 in Great Britain (Shears, 2010).

The horsemeat scandal (also known as Horsegate) began in January 2013 when the Food Safety Authority of Ireland (FSAI) announced the presence of horsemeat in burgers on the shelves of some well-known retailers, such as Tesco, Iceland, Aldi and Lidl (Tse et al., 2016). In 2013, the horsemeat scandal impaired consumer confidence in the transparency of the European food chain to a significant extent. However, on an EU level, the European Commission swiftly responded to the scandal with the adoption of a wide-ranging action plan consisting of targeted policy, legislative and enforcement measures. In the context of food scandals - the horse meat scandal or methanol scandal, the European Commission launched the Administrative Assistance and Cooperation (AAC) System. This IT platform enables crossborder administrative cooperation among national authorities to swiftly obtain information on deceptive and fraudulent activities in the food sector (Montanari et al., 2016; Kubova et al., 2018).

Companies that are certified for compliance with the requirements of one of the standards - BRC, IFS or FSSC 22000 are obliged to carry out food fraud exposure assessment (BRC Global Standard Food Safety issue 8, 2018; International Food Standard, issue 6, 2012; FSSC version 4). As part of such analysis, the fraud and supplier susceptibility to fraud should be assessed.

\section{Company description}

The company, on the example of which will the approach to the implementation of the assessment of susceptibility to food fraud is presented, produces a product - fried onion. Raw materials such as onions, flour, oil, salt and packaging are used to make this product. The company has a modern machine park. Raw material pre-treatment - peeling onions is machine-made. Then, also by machine, the onion is sliced and breaded and fried. The next stage of processing is cooling the product and transporting it to storage tanks. Placement of the finished product into various types of packaging is carried out in accordance with the needs of customers. At the packaging stage, the last element is the detection of metals in the final packaging of the product. This stage is called a CCP (Critical Control Point) and is a functioning part of the company's quality and food safety management system. The enterprise is BRC and IFS certified. The company diversifies purchases, hence the list of suppliers is extensive 5 onion suppliers, 2 flour suppliers, 2 oil suppliers, 4 packaging suppliers, 1 salt supplier. 
A product fraud assessment team has been set up in the company, which is responsible, among other obligations, for conducting a risk assessment to limit product fraud. In case of need, other people, including external experts, are brought in. The teams is supported by top management. The analysis of the team's activities is subject to internal audit. The team uses various data sources that it collects and analyzes (Table 1). On this basis, it carries out the vulnerability assessment process.

\section{Table 1.}

Sources of information on product fraud

\begin{tabular}{|c|c|}
\hline Data source & Examples/ Websites \\
\hline Media & Television, magazines, portals \\
\hline Trade literature & $\begin{array}{l}\text { Przemysł Spożywczy, Opakowanie, Food Safety Magazine, } \\
\text { Towaroznawcze Problemy Jakości } \\
\text { www.tpj.uniwersytetradom.pl }\end{array}$ \\
\hline Industry associations & $\begin{array}{l}\text { Polska Federacja Producentów Żywności Związek Pracodawców } \\
\text { www.pfpz.pl } \\
\text { Krajowa Izba Gospodarcza Przemysłu Spożywczego i Opakowań } \\
\text { www.kig-ps.pl }\end{array}$ \\
\hline Industry portals & $\begin{array}{l}\text { www.portalspozywczy.pl } \\
\text { www.foodfakty.pl }\end{array}$ \\
\hline $\begin{array}{c}\text { RASFF } \\
\text { (Food and Feed Safety } \\
\text { Alerts) }\end{array}$ & https://webgate.ec.europa.eu/rasff-window \\
\hline $\begin{array}{l}\text { EFSA } \\
\text { (European Food Safety } \\
\text { Authority) }\end{array}$ & https://efsa.onlinelibrary.wiley.com/ \\
\hline $\begin{array}{c}\text { AAC } \\
\text { (Administrative Assistance } \\
\text { and Cooperation System) }\end{array}$ & https://ec.europa.eu/food/safety/food-fraud/aas_en \\
\hline $\begin{array}{l}\text { External supervision } \\
\text { authorities }\end{array}$ & $\begin{array}{l}\text { Państwowa Inspekcja Sanitarna (PIS) https://gis.gov.pl } \\
\text { Inspekcja Weterynaryjna (IW) https://www.wetgiw.gov.pl } \\
\text { Inspekcja Handlowa (IH) https://www.uokik.gov.pl } \\
\text { Inspekcja Jakości Handlowej Artykułów Rolno-Spożywczych (IJHARS) } \\
\text { https://ijhars.gov.pl }\end{array}$ \\
\hline
\end{tabular}

\section{Assessment of susceptibility to product fraud in the examined company}

The team conducts susceptibility testing for each raw material, packaging batch, additions or outsourced processes - should they occur. In order to document the product fraud susceptibility assessment process, a product fraud reduction plan was designed ${ }^{1}$.

\footnotetext{
${ }^{1}$ The product fraud mitigation plan sheet and procedure in this company were designed by the author of this publication based on the guidelines of the IFS guide. The IFS guidelines have been developed by the author for the needs of this company.
} 
The vulnerability risk assessment is carried out in the following manner:

a. Product susceptibility risk assessment

- assessment of the likelihood of an event occurring,

- assessment of the likelihood of rapid detection.

b. Supplier vulnerability risk assessment.

c. Assessment of current control measures.

The following risk factors were taken into account when assessing the risk of product vulnerability: historical data on product fraud, economic factors, ease of fraud, complexity of the supply chain, currently used control measures for detecting fraud (IFS Standards. Product Fraud. Guidelines for Implementation, 2018). Based on the matrix from the IFS guide, the probability of occurrence and detection of the above-mentioned risk factors was assessed, and the results were recorded in the designed product fraud reduction plan (Figure 2). The overall product risk score was then obtained.

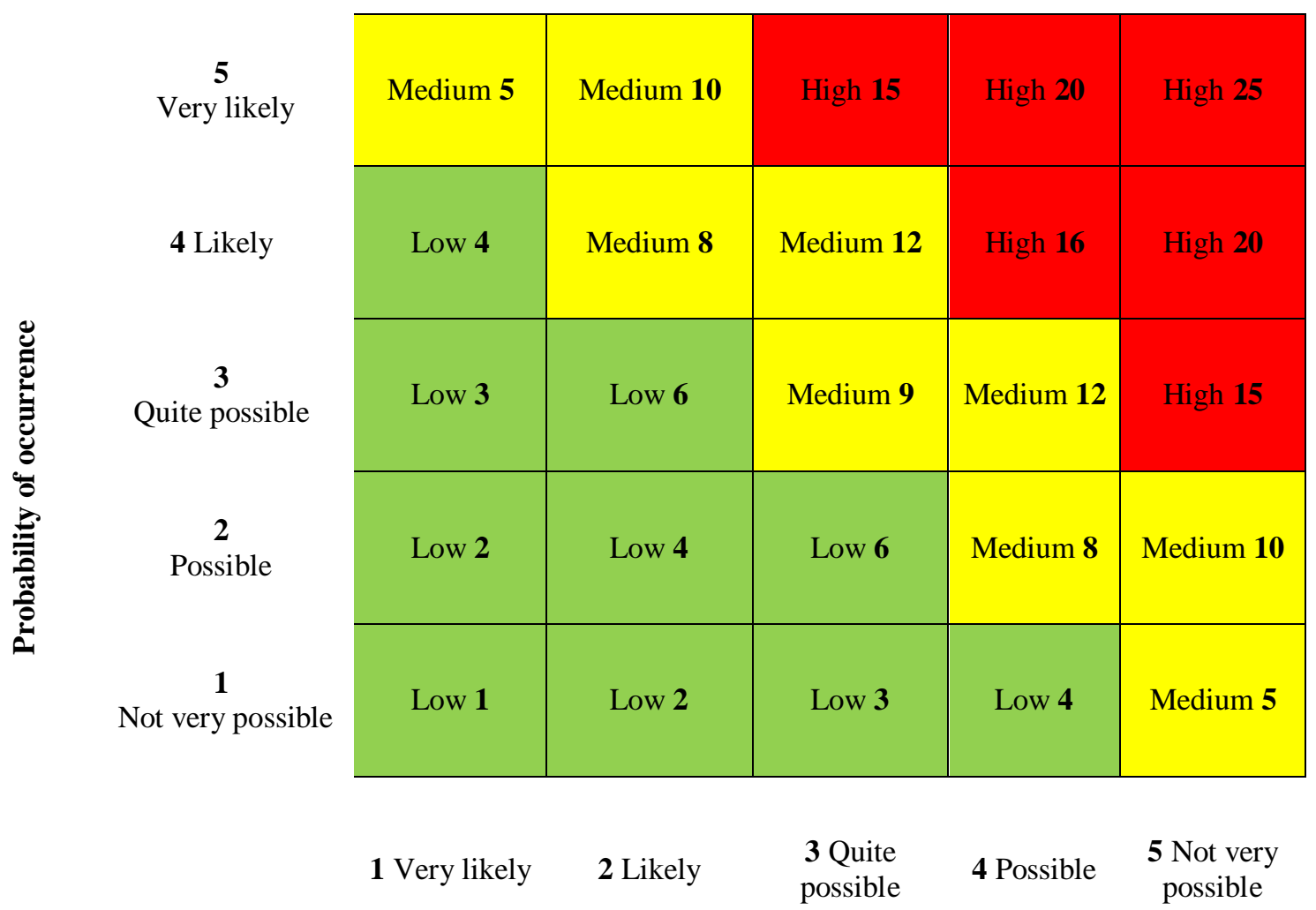

Probability of rapid detection

Figure 2. Risk matrix product vulnerability - the probability of an event and its detection. Adapted from: IFS Standards, 2018. Product Fraud. Guidelines for Implementation. 
Subsequently, the supplier vulnerability risk was assessed, taking into account the following risk factors (IFS Standards. Product Fraud. Guidelines for Implementation, 2018):

- Economic stability of the supplier.

- Were any suppliers affected by layoffs or pay problems?

- Historical data on business contacts with the supplier (complaints, withdrawals).

- Results of qualification and periodic assessment of suppliers.

- Supplier's openness to audit/inspection.

- Supplier management systems used.

- Work ethics in the supplier's region/country (the worse the ethical working conditions at the supplier, the greater the risk).

- Level of legal control in the supplier's region/country (the higher the level, the lower the risk).

Based on the above risk factors, the level of trust in a given supplier was assessed. The overall score was then calculated - multiplying the overall product risk score with the supplier's vulnerability risk score.

The next stage consisted of the team assessing the control measures currently in use in the enterprise in terms of preventing product fraud, including:

- Analytical testing of raw materials, additives, packaging.

- Laboratory analysis certificates.

- Mass balance testing.

- Supplier assessment.

- Surveys for suppliers.

- Checks at the party, frequency of checks.

Evaluation of control measures used can be high, medium or low. For the analyzed enterprise, the criteria taken into account for the assessment of the control measures applied were specified (Table 2).

Table 2.

The criteria adopted for assessing control measures in the company

\begin{tabular}{|c|l|}
\hline $\begin{array}{c}\text { Assessment of } \\
\text { control measures }\end{array}$ & \multicolumn{1}{c|}{ Assessment criteria } \\
\hline High & $\begin{array}{l}\text { The number of control measures } \geq 5 \text {, including mandatory: } \\
\bullet\end{array}$ \\
$\begin{array}{c}\text { analytical testing of raw materials, additives, packaging, } \\
\text { supplier certification towards compliance with the BRC, IFS, FSSC 22000 standard or the }\end{array}$ \\
\hline Medium & $\begin{array}{l}\text { The number of control measures from 3 to 4, including mandatory: } \\
\text { - the supplier is subject to audits or approval based on a questionnaire. }\end{array}$ \\
\hline Low & $\begin{array}{l}\text { The number of control measures from 1 to 2, including control measures implemented in } \\
\text { the plant, do not include analytical testing of raw materials, additives and packaging, } \\
\text { and the supplier is subject to approval only on the basis of a questionnaire. }\end{array}$ \\
\hline
\end{tabular}


As a result of the assessment, the team makes a decision regarding the need for other actions, these may include (IFS Standards. Product Fraud. Guidelines for Implementation, 2018):

- ceasing or limiting the use of raw material, additive, packaging,

- ceasing to use the given supplier (s),

- reducing the purchase of the amount of raw material, additive, packaging from a specific supplier (suppliers),

- change of current control measures depending on the product and control measures, e.g. increased analytical supervision, use of accredited laboratories and methods, increased consumption control, independent pre-shipment control, etc.,

- maintaining the current level of control.

As a result of the assessment, there was no need to change the current proceedings with respect to raw materials and their suppliers. Due to the existing IFS and BRC standards, as well as the high-level culture of food safety and quality, the analyzed company applies high-level controls that allow it to provide protection against adulteration.

The product fraud reduction plan (Table 3) in the examined company is subject to reviews and possible correction by the team at least once a year and whenever there are:

- changes in the supply of raw materials (new supplier, change in the length of the supply chain),

- changes in the supplier's financial position,

- changes in raw material costs,

- changes in the availability of raw materials,

- evidence of fraud detected by control measures (e.g. test results),

- increasing customer complaints that may be related to fraud (e.g. poor product quality),

- information on new ways of falsifying products. 


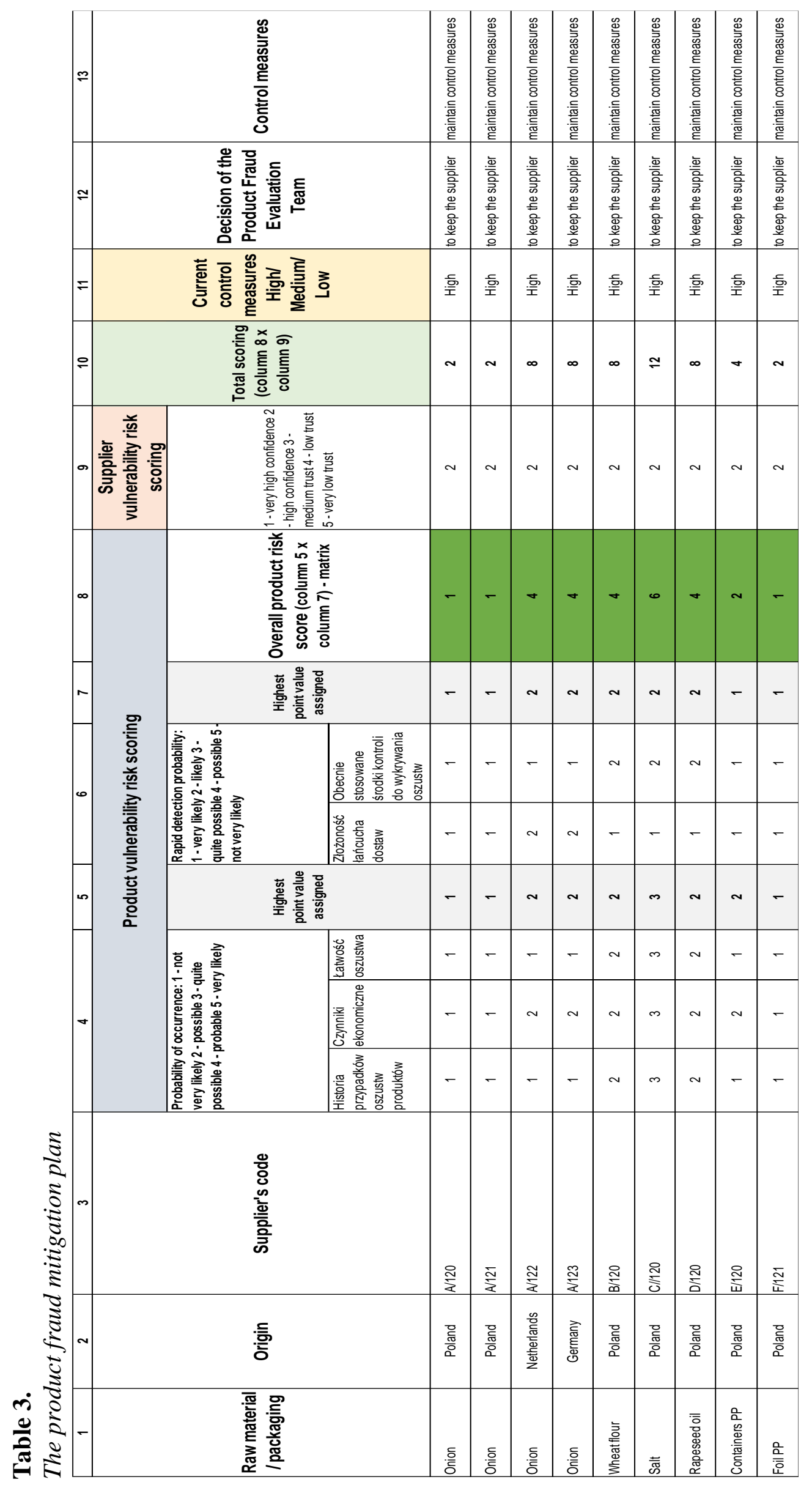




\section{Summary}

The product fraud mitigation plan must be adapted to the specifics of the company, the raw materials used, and the suppliers offering them. In practice, it is a document that must be subject to ongoing evaluation for timeliness. The dynamically changing market and decisions taken by enterprises to increase competitiveness (e.g. purchase of cheaper raw materials) may contribute to increasing the likelihood of product fraud. How this area is regulated in enterprises largely depends on the culture of safety and the quality of food that is shaped in them. The analyzed company is characterized by a high level of culture of food safety and quality, actions are taken there to support its development at various levels, such as leadership, communication, employee involvement, and risk awareness. This approach guarantees that the developed product fraud reduction plan will evolve in this company depending on changing risk factors.

\section{References}

1. BRC Global Standard Food Safety, 8/2018.

2. Górna, J. (2018). Społeczna odpowiedzialność przedsiębiorstw w zakresie przestrzegania zasad higieny na etapie produkcji podstawowej. Zagadnienia Doradztwa Rolniczego, 1.

3. Górna, J. (2019). Zarządzanie bezpieczeństwem żywności. In: J. Łańcucki (Ed.), Systemy zarządzania $w$ znormalizowanym świecie. Wydawnictwo Uniwersytetu Ekonomicznego w Poznaniu.

4. IFS Standards (2018). Product Fraud. Guidelines for Implementation.

5. International Food Standard, 6/2012. Berlin: HDE Trade Services.

6. Koubova, J., Samkova, E., Hasonova, L. (2018). Food fraud detection by Chech Agricultural and Food Inspection Authority in retail market. British Food Journal, 120, 4.

7. Manning, L., Baines, R.N. (2004). Effective management of food safety and quality. British Food Journal, 106, 8.

8. Montanari, F., Varallo, C., Pisanello, D. (2016). Food fraud in the EU. Cambridge University Press, 7, 1.

9. Shears, P. (2010). Food fraud - a current issue but not an old problem. British Food Journal, $112,2$.

10. Sumar, S., Ismail, H. (1995). Adilteration of foods - past and present. Nitrition \& Food Science, 4.

11. Tse, K.Y., Zhang, M., Doherty, B., Chappell, P., Garnett, P. (2016). Insight from the horsemeat scandal. Exploring the consumers' opinion of tweets toward Tesco. Industrial Management \& Data Systems, 116, 6.

12. www.fssc22000.com, 20.10.2019. 